\title{
Risk assessment of the presence of various organic and inorganic compounds in oil flows in different units of refineries by methods of FMEA and PHA
}

\author{
Mehrzad Zandieh \\ Department of Chemical Engineering, Faculty of Engineering, Razi University, Kermanshah, Iran \\ mehrzad.zandieh@yahoo.com
}

\begin{abstract}
In this new and applied study, it has been investigated the risks of presence of Nitrogenous organic compounds such as quinoline and indole and Naphthenic acids and various inorganic compounds (S, FeS, $\mathrm{H}_{2} \mathrm{~S}$, water, inorganic salts, Sediment) in oil flows in different units of refineries. Hazards, their effects and related causes were identified. Control and preventive actions was suggested for decreasing risks. Results showed that with applying control and preventive actions, risk numbers decreased significantly for both FMEA and PHA methods. These showed that all control and preventive actions were fully effectiveness and appropriately.
\end{abstract}

Key words: FMEA, PHA, Risk assessment, Refinery, organic, inorganic components.

\section{Introduction}

There is often a negative attitude among the population in the society about the risk concept. They have considered it as a sign of a damage ، danger and negative effects as well as fail probability toward achieving the predefined goals of the considered project [1]. While Britain Standards Institute, knows risk as combination of occurrence and results of a hazardous event [2].

Risk assessment determines the qualitative analysis of risk potential regarding the sensitivity or vulnerability of the surrounding environment [3]. In general, there are currently more than 70 risk assessment methods in the world which are divided in to two qualitative and quantitative groups [4].

Quantitative assessment focuses on risk factors and preventive measures and is done to eliminate or prevent risks [5]. Failure modes and effects analysis (FMEA) is one of the modern methods of assessment and risk management in oil, gas and petrochemical industries [6].

The purpose of FMEA is to increase process reliability by preventing the system identified failures and reducing the adverse consequences thereof. FEMA requires detailed and detailed information about the system under investigation [7-9].

Tae-guKim Jeong (2002) [10] studied focuses on the current status of risk management activities conducted by the petrochemical plants in Korea, and on the trends in the global market.

M. Jabbari Gharabagh (2009) [11] studied comprehensive risk assessment and management of petrochemical feed and product transportation pipelines. In this research, using probabilistic and indexing models, an algorithm is developed, which overcomes most of the limitations of the models. , the results of the relative risk assessment indices were used as an adjusting factor to correct the pipeline failure rate and to develop an algorithm for the comprehensive risk assessment technique. Sensitivity analysis of the algorithm was carried out. The present algorithm enables the identification of most of the pipeline failure causes.

Rong-Hwa Huang (2012) [12] studied an assessment model that examines quantity and quality factors for equipment risk management in the petrochemical industry. The proposed model had five dimensions-financial performance, logistical support, service level, learning and innovation, and risk control. Proposed model provided a valuable reference for decision-making in equipment risk management.

XU Xiaonan (2012) [13] studied Leakage frequency of ethylene horizontal tanks and its attachments and may lead to risk accident were analyzed by SAFETI and leak quantitative risk analysis software of Norwegian DNV company. Through the simulation results of four accident Scene, which gas leakage of the tank, tank rupture, leakage in the pipe from the tank to the pump, leakage in the pump and its export pipe, evaluated the effect of leakage, radiation, explosion to the staff and installations in the factory so that Determined the risk of casualties and property loss in ethylene tank farm. 
Wei Wu Guang (2013) [14] studied Risk analysis of corrosion failures of equipment in refining and petrochemical plants based on fuzzy set theory. In this model, two essential parts of failure risk (i.e., failure likelihood and severity of failure consequence) are first estimated by using fuzzy synthetic evaluation. The results show that this model is effective and feasible.

In this study, for the first time, it was studied risk assessment of presence of different mineral and organic compounds in oil streams in different units of refineries with FMEA and PHA methods.

\section{Methodology}

\subsection{PHA Methodology}

Risk assessment matrix in table 1 shows severity of dangers and probabilities of occurrence.

Table 1: Risk assessment Matrix in PHA method

\begin{tabular}{|c|c|c|c|c|}
\hline \multicolumn{3}{|c|}{ Risk Assessment Matrix } \\
\hline Partial (4) & Boundary (3) & Critical (2) & Disastrous (1) & Peverity of danger \\
& & & & $\begin{array}{c}\text { Probability of } \\
\text { occurrence }\end{array}$ \\
\hline 4A & 3A & 2A & $1 \mathrm{~A}$ & Repeated (A) \\
\hline 4B & 3B & 2B & 1B & Possible (B) \\
\hline 4C & 3C & 2C & 1C & Occasional (C) \\
\hline 4D & 3D & 2D & 1D & Very little (D) \\
\hline 4E & 3E & 2E & 1E & Improbable (E) \\
\hline
\end{tabular}

Table 2 shows the risk criteria and risk classification. Every risk criteria relates to oneself risk classification.

Table 2: Risk criteria and its related classification in PHA method

\begin{tabular}{|c|c|}
\hline Risk classification & Risk criteria \\
\hline 1A, 1B, 1C, 2A, 2B, 3A & unacceptable \\
\hline 1D, 2C, 2D, 3B, 3C & Undesirable \\
\hline 1E, 2E, 3D, 3E, 4A, 4B & Acceptable but with the need for revision \\
\hline 4C, 4D, 4E & Acceptable without revision \\
\hline
\end{tabular}

\subsection{FMEA Methodology}

Chemical Engineer of process design is the primary responsibility for risk assessment.

Next step is identifying the Potential Failure Modes that occurs in the defined operation.

The potential impacts are the consequence and consequence of Potential Failure Modes that occur on the next level operations.

Severity is intensifying of the rating that indicates how serious the damage caused on the product.

Potential Cause/ Mechanism of Failure: Identify process deficiencies and deficiencies that can cause failure.

Occurrence: The number of occurrences is the rank associated with the probability of a crash occurring.

Current Process Control: There are methods and techniques used to prevent failure (or causes of failure) or to identify failure (or causes) at the same production facility or subsequent stations (before leaving the product out of process).

Rank detection: The diagnosis is an estimate of the probability that current process controls can detect the state of failure or the cause of the failure before leaving the manufacturing process or assembly. In determining the rating, you must examine the ability of these controls to detect the state or cause of the crash.

Table 3 shows the frequency of occurrence of defects $(\mathrm{O})$ that includes rating, percentage of occurrence and check the probability of a fault. 
Table 3: Occurrence of defects $(\mathrm{O})$

\begin{tabular}{|c|c|c|}
\hline \multicolumn{3}{|c|}{ The frequency of occurrence of defects (O) } \\
\hline Check the probability of a fault & Percentage of occurrence & RATING \\
\hline $\begin{array}{c}\text { Very high; The occurrence of flaw } \\
\text { is almost certain. }\end{array}$ & 1 defect per 10 items & 10 \\
1 defect per 20 items & 9 \\
\hline High; Defects usually happen. & 1 defect per 100 items & 8 \\
\hline Medium; Fatigue sometimes & 1 defect per 200 items & 7 \\
\hline happens . & 1 defect per 500 items & 6 \\
\hline \multirow{2}{*}{ Little; Flaw rarely happens. } & 1 defect per 2000 items & 5 \\
\hline Unlikely & 1 defect per 5000 items & 3 \\
\hline
\end{tabular}

Table 4 shows detection scale (D) that includes rating, detection capability and fault detection review.

Table 4: Detection Scale (D)

\begin{tabular}{|c|c|c|}
\hline \multicolumn{3}{|l|}{ (D) Detection scale } \\
\hline Fault Detection Review & $\begin{array}{l}\text { Detection } \\
\text { capability }\end{array}$ & RATING \\
\hline $\begin{array}{l}\text { There is no control over the process, or existing controls cannot determine the } \\
\text { cause of the fault mechanism. }\end{array}$ & $\begin{array}{l}\text { Absolutely } \\
\text { impossible }\end{array}$ & 10 \\
\hline $\begin{array}{l}\text { The likelihood that existing controls can detect the fault mechanism and the } \\
\text { occurrence of a fault is unlikely. }\end{array}$ & $\begin{array}{l}\text { Very } \\
\text { unlikely }\end{array}$ & 9 \\
\hline $\begin{array}{l}\text { The likelihood that existing controls can detect the fault and failure } \\
\text { mechanism is very rare. }\end{array}$ & Unlikely & 8 \\
\hline $\begin{array}{l}\text { The likelihood that existing controls can detect the fault and failure } \\
\text { mechanism is very limited. }\end{array}$ & Very little & 7 \\
\hline $\begin{array}{l}\text { The probability that existing controls can detect the fault and defect } \\
\text { mechanism is low. }\end{array}$ & little & 6 \\
\hline $\begin{array}{l}\text { The probability that existing controls can detect the fault and defect } \\
\text { mechanism is moderate. }\end{array}$ & medium & 5 \\
\hline $\begin{array}{l}\text { The probability that existing controls can detect the fault and defect } \\
\text { mechanism is moderate to high. }\end{array}$ & $\begin{array}{l}\text { Moderate to } \\
\text { high }\end{array}$ & 4 \\
\hline $\begin{array}{l}\text { The probability that existing controls can detect the fault and defect } \\
\text { mechanism is high. }\end{array}$ & High & 3 \\
\hline $\begin{array}{l}\text { The probability that existing controls can detect the fault and defect } \\
\text { mechanism is very high. }\end{array}$ & Very high & 2 \\
\hline $\begin{array}{l}\text { The existing process controls will almost completely detect the cause of the } \\
\text { fault and fault mechanism. }\end{array}$ & $\begin{array}{l}\text { Almost } \\
\text { complete }\end{array}$ & 1 \\
\hline
\end{tabular}

RPN, Risk number is calculated by following formula:

$\mathrm{RPN}=\mathrm{S} * \mathrm{O} * \mathrm{D}$

Where: $\mathrm{S}$ is Severity, $\mathrm{O}$ is Occurrence, D is Detection and RPN is degree of risk. 


\section{Results and discussions}

Table 5: PHA risk assessment

\begin{tabular}{|c|c|c|c|c|c|c|}
\hline \multicolumn{7}{|c|}{ PHA } \\
\hline $\begin{array}{l}\text { Risk level } \\
\text { after } \\
\text { control } \\
\text { actions }\end{array}$ & $\begin{array}{c}\text { Control and } \\
\text { preventive actions }\end{array}$ & $\begin{array}{l}\text { Risk } \\
\text { level }\end{array}$ & Effects & Causes & Hazards & Row \\
\hline $3 \mathbf{E}$ & $\begin{array}{c}\text { Sulfur pre- } \\
\text { purification } \\
\text { operations } \\
\text { (desulphurization) }\end{array}$ & 3D & $\begin{array}{c}\text { Reducing the } \\
\text { useful life of the } \\
\text { unit reforming } \\
\text { Catalyst }\end{array}$ & $\begin{array}{l}\text { The presence of } \\
\text { sulfur } \\
\text { compounds in } \\
\text { the flow of feed } \\
\text { to the reforming } \\
\text { unit }\end{array}$ & $\begin{array}{c}\text { Creating } \\
\text { poisoning in the } \\
\text { Reforming unit } \\
\text { Catalyst }\end{array}$ & 1 \\
\hline $3 \mathbf{E}$ & $\begin{array}{c}\text { Sulfur removal from } \\
\text { the final product } \\
\text { with separation } \\
\text { operation }\end{array}$ & 3D & $\begin{array}{l}\text { Decrease the } \\
\text { quality of final } \\
\text { products due to } \\
\text { color change }\end{array}$ & $\begin{array}{c}\text { Absence of } \\
\text { complete } \\
\text { purification of } \\
\text { sulfur } \\
\text { compounds in } \\
\text { pre-treatment } \\
\text { stages } \\
\end{array}$ & $\begin{array}{l}\text { Presence of low } \\
\text { amounts of } \\
\text { sulfur } \\
\text { compounds in } \\
\text { the final product }\end{array}$ & 2 \\
\hline $2 \mathbf{E}$ & $\begin{array}{l}\text { Covering the } \\
\text { external wall of the } \\
\text { pipelines with } \\
\text { irreversible and non- } \\
\text { oxidizing coatings } \\
\text { with air } \\
\end{array}$ & 2D & fire & $\begin{array}{l}\text { The presence of } \\
\text { iron sulfide } \\
\text { compounds in } \\
\text { the tube wall }\end{array}$ & $\begin{array}{c}\text { Contact iron } \\
\text { sulfide pipelines } \\
\text { and air }\end{array}$ & 3 \\
\hline $3 \mathbf{E}$ & $\begin{array}{l}\text { The use of a cover on } \\
\text { the inner side of the } \\
\text { storage tank that } \\
\text { does not react with } \\
\text { hydrogen dioxide }\end{array}$ & 3D & $\begin{array}{c}\text { Corrosion in the } \\
\text { walls of storage } \\
\text { tanks }\end{array}$ & $\begin{array}{c}\text { Presence of } \\
\text { more than } 6 \\
\text { ppm } \\
\text { Hydrogen } \\
\text { sulfide dissolved } \\
\text { in oil } \\
\end{array}$ & $\begin{array}{l}\text { Formation of } \\
\text { iron sulfide } \\
\text { deposits }\end{array}$ & 4 \\
\hline $3 E$ & $\begin{array}{l}\text { Injectable non- } \\
\text { harmful acid for the } \\
\text { catalyst to adjust its } \\
\text { acidity }\end{array}$ & 3D & $\begin{array}{l}\text { Reduced acidity } \\
\text { of refined } \\
\text { catalysts in } \\
\text { conversion units } \\
\text { such as cracking } \\
\text { and reforming }\end{array}$ & $\begin{array}{c}\text { The } \\
\text { degradation of } \\
\text { nitrogen } \\
\text { compounds } \\
\text { such as } \\
\text { quinoline and } \\
\text { indole } \\
\end{array}$ & $\begin{array}{c}\text { Creating organic } \\
\text { bases or } \\
\text { ammonia }\end{array}$ & 5 \\
\hline $2 E$ & $\begin{array}{l}\text { Pre-treatment of } \\
\text { crude oil before } \\
\text { entering the reactor }\end{array}$ & 2D & $\begin{array}{l}\text { Equipment } \\
\text { destruction }\end{array}$ & $\begin{array}{l}\text { Presence of low } \\
\text { amounts of } \\
\text { water, sediment } \\
\text { and mineral } \\
\text { salts }\end{array}$ & $\begin{array}{c}\text { Creation of } \\
\text { corrosion, } \\
\text { abrasion, } \\
\text { sedimentation, } \\
\text { blockage and } \\
\text { catalyst } \\
\text { poisoning } \\
\end{array}$ & 6 \\
\hline $2 E$ & $\begin{array}{l}\text { Use the appropriate } \\
\text { gender for the piping } \\
\text { system and the } \\
\text { connections in such a } \\
\text { way that the oil flow } \\
\text { does not corrode the } \\
\text { fluid transfer system }\end{array}$ & 2D & $\begin{array}{l}\text { Blockage of } \\
\text { pipelines and } \\
\text { contamination } \\
\text { of products }\end{array}$ & $\begin{array}{l}\text { Abrasion of } \\
\text { pipelines, } \\
\text { storage tanks, } \\
\text { valves and } \\
\text { plumbing } \\
\text { systems }\end{array}$ & $\begin{array}{l}\text { Formation of } \\
\text { free compounds } \\
\text { such as iron, } \\
\text { copper, lead, } \\
\text { nickel and } \\
\text { vanadium }\end{array}$ & 7 \\
\hline $2 \mathbf{E}$ & Water injection & 2D & $\begin{array}{c}\text { Reduce } \\
\text { production }\end{array}$ & $\begin{array}{c}\text { The presence of } \\
\text { sodium chloride } \\
\text { salt } \\
\text { precipitation }\end{array}$ & $\begin{array}{l}\text { Reducing the } \\
\text { internal } \\
\text { diameter of the } \\
\text { extraction pipe }\end{array}$ & 8 \\
\hline
\end{tabular}




\begin{tabular}{|c|c|c|c|c|c|c|}
\hline & & & & $\begin{array}{c}\text { due to partial } \\
\text { evaporation of } \\
\text { water due to the } \\
\text { drop in pressure } \\
\text { between the } \\
\text { head and } \\
\text { bottom of the } \\
\text { well in the } \\
\text { exhaust pipe } \\
\text { wall }\end{array}$ & & \\
\hline $3 \mathbf{E}$ & $\begin{array}{l}\text { Prefiltration before } \\
\text { the flow inlet into the } \\
\text { heat exchangers of } \\
\text { the shell and pipe }\end{array}$ & 3D & $\begin{array}{c}\text { Formation of } \\
\text { hot spots and } \\
\text { formation of } \\
\text { coke, especially } \\
\text { in warmer heat } \\
\text { exchangers }\end{array}$ & $\begin{array}{l}\text { In refining } \\
\text { processes, salt } \\
\text { sedimentation } \\
\text { in the heat } \\
\text { exchanger tubes }\end{array}$ & $\begin{array}{l}\text { Reduce heat } \\
\text { transfer }\end{array}$ & 9 \\
\hline $3 \mathbf{E}$ & $\begin{array}{l}\text { Pre-treatment of salt } \\
\text { with filtration and } \\
\text { precipitate }\end{array}$ & 3D & $\begin{array}{l}\text { Reduce heat } \\
\text { transfer }\end{array}$ & $\begin{array}{l}\text { The presence of } \\
\text { salt in the } \\
\text { supply of heavy } \\
\text { fuel }\end{array}$ & Eclipse burners & 10 \\
\hline $3 \mathbf{E}$ & $\begin{array}{l}\text { Pre-treatment of salt } \\
\text { with filtration and } \\
\text { precipitate }\end{array}$ & 3D & $\begin{array}{l}\text { Lack of proper } \\
\text { asphalt } \\
\text { formation }\end{array}$ & $\begin{array}{c}\text { The presence of } \\
\text { salt in the } \\
\text { asphalt unit } \\
\text { feed }\end{array}$ & $\begin{array}{l}\text { Disturbance of } \\
\text { asphalt } \\
\text { emulsions }\end{array}$ & 11 \\
\hline $3 \mathbf{E}$ & $\begin{array}{l}\text { Pre-treatment of salt } \\
\text { with filtration and } \\
\text { precipitate }\end{array}$ & 3D & $\begin{array}{l}\text { Reduce the } \\
\text { quality of coke } \\
\text { production }\end{array}$ & $\begin{array}{l}\text { The presence of } \\
\text { salt in the input } \\
\text { feed of } \\
\text { petrochemical } \\
\text { coke production } \\
\text { unit }\end{array}$ & $\begin{array}{l}\text { Coming down } \\
\text { the percentage } \\
\text { of coke in the } \\
\text { final product }\end{array}$ & 12 \\
\hline $3 \mathbf{E}$ & $\begin{array}{l}\text { Injection of alkaline } \\
\text { materials at points in } \\
\text { the distillation } \\
\text { column where water } \\
\text { is condensed }\end{array}$ & 3D & $\begin{array}{l}\text { corrosion of the } \\
\text { distillation } \\
\text { tower and } \\
\text { corrosion of the } \\
\text { condenser shell } \\
\text { or wall of the } \\
\text { condenser pipes }\end{array}$ & $\begin{array}{l}\text { The presence of } \\
\text { magnesium } \\
\text { chloride salts } \\
\text { and calcium } \\
\text { chloride in the } \\
\text { distillation } \\
\text { tower }\end{array}$ & $\begin{array}{l}\text { Hydrolysis of } \\
\text { magnesium } \\
\text { chloride and } \\
\text { calcium chloride } \\
\text { at a temperature } \\
\text { above } 120{ }^{\circ} \mathrm{C}, \\
\text { resulting in the } \\
\text { release of } \\
\text { dissolved } \\
\text { hydrogen } \\
\text { chloride in the } \\
\text { top of the } \\
\text { distillation tower } \\
\text { of crude oil or } \\
\text { condenser }\end{array}$ & 13 \\
\hline $3 \mathbf{E}$ & Pretreatment & $3 \mathrm{C}$ & $\begin{array}{l}\text { Reducing the } \\
\text { quality of } \\
\text { products } \\
\text { produced from } \\
\text { catalytic } \\
\text { cracking and } \\
\text { refining units }\end{array}$ & $\begin{array}{l}\text { The presence of } \\
\text { salts in the feed } \\
\text { into catalytic } \\
\text { cracking and } \\
\text { refining units }\end{array}$ & $\begin{array}{l}\text { Deactivation of } \\
\text { catalysts of } \\
\text { catalytic } \\
\text { cracking units } \\
\text { and refinement }\end{array}$ & 14 \\
\hline $3 \mathbf{E}$ & $\begin{array}{c}\text { The use of } \\
\text { irreplaceable } \\
\text { materials-by the use } \\
\text { of naphthenic acid-in } \\
\text { the equipment }\end{array}$ & $3 \mathrm{C}$ & Corrosive & $\begin{array}{l}\text { The presence of } \\
\text { naphthenic } \\
\text { acids in crude } \\
\text { oil and oil cuts }\end{array}$ & $\begin{array}{c}\text { Formation of } \\
\text { stable emulsions } \\
\text { with caustic } \\
\text { solution during } \\
\text { desalination or } \\
\text { oil production } \\
\end{array}$ & 15 \\
\hline
\end{tabular}


Table 6: FMEA risk assessment

\begin{tabular}{|c|c|c|c|c|c|c|c|c|c|c|c|}
\hline \multicolumn{12}{|c|}{ FMEA } \\
\hline \multicolumn{12}{|c|}{$\begin{array}{c}\text { RPN=72 } \\
\text { After control actions } \quad R P N=24\end{array}$} \\
\hline \multicolumn{4}{|c|}{ Action Results } & \multirow[b]{2}{*}{$\begin{array}{l}\text { Preventive and } \\
\text { control actions }\end{array}$} & \multirow{2}{*}{$\begin{array}{l}\text { Degree } \\
\text { of risk } \\
\text { (RPN) }\end{array}$} & \multirow{2}{*}{$\begin{array}{c}\text { Detectio } \\
\quad n \\
\text { coefficie } \\
\text { nt (D) }\end{array}$} & \multirow[b]{2}{*}{$\begin{array}{l}\text { Occurrenc } \\
\text { e (O) }\end{array}$} & \multirow[b]{2}{*}{$\begin{array}{l}\text { Severity } \\
\text { (S) }\end{array}$} & \multirow[b]{2}{*}{$\begin{array}{c}\text { Causes of } \\
\text { occurrence }\end{array}$} & \multirow[b]{2}{*}{ Hazards } & \multirow[b]{2}{*}{$\stackrel{8}{\approx}$} \\
\hline $\begin{array}{l}\mathbf{R} \\
\mathbf{P} \\
\mathbf{N}\end{array}$ & $\begin{array}{l}\mathbf{D} \\
\mathbf{E} \\
\mathbf{T}\end{array}$ & $\begin{array}{l}\text { O } \\
\text { C } \\
\text { C }\end{array}$ & $\begin{array}{l}\text { S } \\
\text { E } \\
\text { V }\end{array}$ & & & & & & & & \\
\hline 21 & 3 & 1 & 7 & $\begin{array}{c}\text { Sulfur pre- } \\
\text { purification } \\
\text { operations } \\
\text { (desulphurizatio } \\
\text { n) }\end{array}$ & 63 & 3 & 3 & 7 & $\begin{array}{l}\text { The presence } \\
\text { of sulfur } \\
\text { compounds } \\
\text { in the flow of } \\
\text { feed to the } \\
\text { reforming } \\
\text { unit }\end{array}$ & $\begin{array}{c}\text { Creating } \\
\text { poisoning } \\
\text { in the } \\
\text { Reforming } \\
\text { unit } \\
\text { Catalyst }\end{array}$ & 1 \\
\hline 12 & 4 & 1 & 3 & $\begin{array}{l}\text { Sulfur removal } \\
\text { from the final } \\
\text { product with } \\
\text { separation } \\
\text { operation }\end{array}$ & 36 & 4 & 3 & 3 & $\begin{array}{c}\text { Absence of } \\
\text { complete } \\
\text { purification } \\
\text { of sulfur } \\
\text { compounds } \\
\text { in pre- } \\
\text { treatment } \\
\text { stages }\end{array}$ & $\begin{array}{c}\text { Presence of } \\
\text { low } \\
\text { amounts of } \\
\text { sulfur } \\
\text { compounds } \\
\text { in the final } \\
\text { product }\end{array}$ & 2 \\
\hline 27 & 3 & 1 & 9 & $\begin{array}{c}\text { Covering the } \\
\text { external wall of } \\
\text { the pipelines } \\
\text { with irreversible } \\
\text { and non- } \\
\text { oxidizing } \\
\text { coatings with air }\end{array}$ & 81 & 3 & 3 & 9 & $\begin{array}{c}\text { The presence } \\
\text { of iron } \\
\text { sulfide } \\
\text { compounds } \\
\text { in the tube } \\
\text { wall }\end{array}$ & $\begin{array}{c}\text { Contact } \\
\text { iron sulfide } \\
\text { pipelines } \\
\text { and air }\end{array}$ & 3 \\
\hline 18 & 3 & 1 & 6 & $\begin{array}{l}\text { The use of a } \\
\text { cover on the } \\
\text { inner side of the } \\
\text { storage tank that } \\
\text { does not react } \\
\text { with hydrogen } \\
\text { dioxide }\end{array}$ & 72 & 3 & 4 & 6 & $\begin{array}{c}\text { Presence of } \\
\text { more than } 6 \\
\text { ppm } \\
\text { Hydrogen } \\
\text { sulfide } \\
\text { dissolved in } \\
\text { oil } \\
\end{array}$ & $\begin{array}{l}\text { Formation } \\
\text { of iron } \\
\text { sulfide } \\
\text { deposits }\end{array}$ & 4 \\
\hline 12 & 3 & 1 & 4 & $\begin{array}{l}\text { Injectable non- } \\
\text { harmful acid for } \\
\text { the catalyst to } \\
\text { adjust its acidity }\end{array}$ & 36 & 3 & 3 & 4 & $\begin{array}{c}\text { degradation } \\
\text { of nitrogen } \\
\text { compounds } \\
\text { such as } \\
\text { quinoline } \\
\text { and indole } \\
\end{array}$ & $\begin{array}{c}\text { Creating } \\
\text { organic } \\
\text { bases or } \\
\text { ammonia }\end{array}$ & 5 \\
\hline 28 & 4 & 1 & 7 & $\begin{array}{l}\text { Pre-treatment of } \\
\text { crude oil before } \\
\text { entering the } \\
\text { reactor }\end{array}$ & 84 & 4 & 3 & 7 & $\begin{array}{c}\text { Presence of } \\
\text { low amounts } \\
\text { of water, } \\
\text { sediment } \\
\text { and mineral } \\
\text { salts }\end{array}$ & $\begin{array}{c}\text { Creation of } \\
\text { corrosion, } \\
\text { abrasion, } \\
\text { sedimentati } \\
\text { on, } \\
\text { blockage } \\
\text { and } \\
\text { catalyst } \\
\text { poisoning }\end{array}$ & 6 \\
\hline 24 & 3 & 1 & 8 & $\begin{array}{l}\text { Use the } \\
\text { appropriate } \\
\text { gender for the } \\
\text { piping system }\end{array}$ & 72 & 3 & 3 & 8 & $\begin{array}{l}\text { Abrasion of } \\
\text { pipelines, } \\
\text { storage } \\
\text { tanks, valves }\end{array}$ & $\begin{array}{c}\text { Formation } \\
\text { of free } \\
\text { compounds } \\
\text { such as } \\
\end{array}$ & 7 \\
\hline
\end{tabular}




\begin{tabular}{|c|c|c|c|c|c|c|c|c|c|c|c|}
\hline & & & & $\begin{array}{c}\text { and the } \\
\text { connections in } \\
\text { such a way that } \\
\text { the oil flow does } \\
\text { not corrode the } \\
\text { fluid transfer } \\
\text { system }\end{array}$ & & & & & $\begin{array}{c}\text { and } \\
\text { plumbing } \\
\text { systems }\end{array}$ & $\begin{array}{c}\text { iron, } \\
\text { copper, } \\
\text { lead, nickel } \\
\text { and } \\
\text { vanadium }\end{array}$ & \\
\hline 21 & 3 & 1 & 7 & Water injection & 63 & 3 & 3 & 7 & $\begin{array}{c}\text { The presence } \\
\text { of sodium } \\
\text { chloride salt } \\
\text { precipitation } \\
\text { due to } \\
\text { partial } \\
\text { evaporation } \\
\text { of water due } \\
\text { to the drop } \\
\text { in pressure } \\
\text { between the } \\
\text { head and } \\
\text { bottom of } \\
\text { the well in } \\
\text { the exhaust } \\
\text { pipe wall }\end{array}$ & $\begin{array}{c}\text { Reducing } \\
\text { the internal } \\
\text { diameter of } \\
\text { the } \\
\text { extraction } \\
\text { pipe }\end{array}$ & 8 \\
\hline 18 & 3 & 1 & 6 & $\begin{array}{l}\text { Prefiltration } \\
\text { before the flow } \\
\text { inlet into the } \\
\text { heat exchangers } \\
\text { of shell and tube }\end{array}$ & 54 & 3 & 3 & 6 & $\begin{array}{c}\text { In refining } \\
\text { processes, } \\
\text { salt } \\
\text { sedimentatio } \\
\mathbf{n} \text { in the heat } \\
\text { exchanger } \\
\text { tubes }\end{array}$ & $\begin{array}{l}\text { Reduce } \\
\text { heat } \\
\text { transfer }\end{array}$ & 9 \\
\hline 15 & 3 & 1 & 5 & $\begin{array}{c}\text { Pre-treatment of } \\
\text { salt with } \\
\text { filtration and } \\
\text { precipitate }\end{array}$ & 45 & 3 & 3 & 5 & $\begin{array}{c}\text { The presence } \\
\text { of salt in the } \\
\text { supply of } \\
\text { heavy fuel }\end{array}$ & $\begin{array}{c}\text { Eclipse } \\
\text { burners }\end{array}$ & 10 \\
\hline 18 & 3 & 1 & 6 & $\begin{array}{l}\text { Pre-treatment of } \\
\text { salt with } \\
\text { filtration and } \\
\text { precipitate }\end{array}$ & 54 & 3 & 3 & 6 & $\begin{array}{c}\text { The presence } \\
\text { of salt in the } \\
\text { asphalt unit } \\
\text { feed }\end{array}$ & $\begin{array}{c}\text { Disturbanc } \\
\text { e of asphalt } \\
\text { emulsions }\end{array}$ & 11 \\
\hline 21 & 3 & 1 & 7 & $\begin{array}{l}\text { Pre-treatment of } \\
\text { salt with } \\
\text { filtration and } \\
\text { precipitate }\end{array}$ & 63 & 3 & 3 & 7 & $\begin{array}{l}\text { The presence } \\
\text { of salt in the } \\
\text { input feed of } \\
\text { petrochemic } \\
\text { al coke } \\
\text { production } \\
\text { unit }\end{array}$ & $\begin{array}{l}\text { Coming } \\
\text { down the } \\
\text { percentage } \\
\text { of coke in } \\
\text { the final } \\
\text { product }\end{array}$ & 12 \\
\hline 18 & 3 & 1 & 6 & $\begin{array}{l}\text { Injection of } \\
\text { alkaline } \\
\text { materials at } \\
\text { points in the } \\
\text { distillation } \\
\text { column where } \\
\text { water is } \\
\text { condensed }\end{array}$ & 54 & 3 & 3 & 6 & $\begin{array}{c}\text { The presence } \\
\text { of } \\
\text { magnesium } \\
\text { chloride salts } \\
\text { and calcium } \\
\text { chloride in } \\
\text { the } \\
\text { distillation } \\
\text { tower }\end{array}$ & $\begin{array}{c}\begin{array}{c}\text { Hydrolysis } \\
\text { of }\end{array} \\
\text { magnesium } \\
\text { chloride } \\
\text { and } \\
\text { calcium } \\
\text { chloride at } \\
\text { a } \\
\text { temperatur } \\
\text { e above } 120 \\
\text { ० C, } \\
\text { resulting in } \\
\text { the release } \\
\text { of dissolved }\end{array}$ & 13 \\
\hline
\end{tabular}




\begin{tabular}{|c|l|l|l|l|l|l|l|l|l|}
\hline & & & & & & & & & \\
&
\end{tabular}

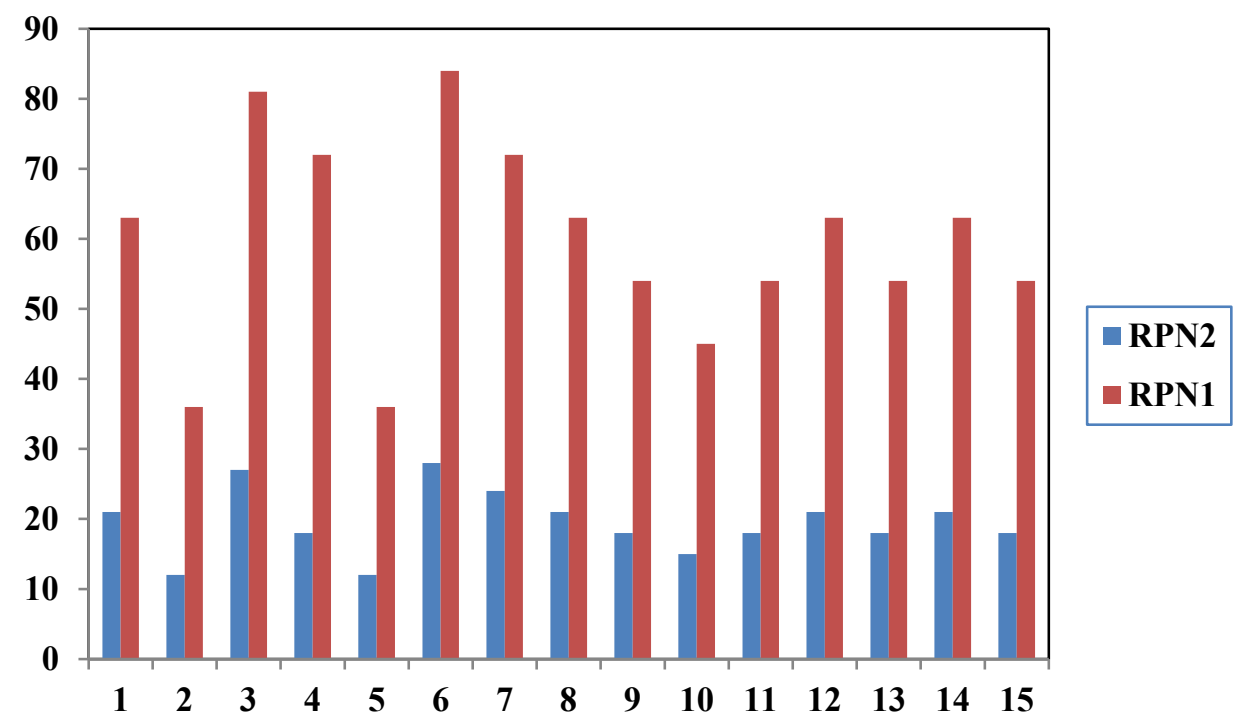

Figure 1: $\mathrm{RPN}_{1}, \mathrm{RPN}_{2} ; \mathrm{RPN}_{1}$ is risk numbers before control and preventive actions, $\mathrm{RPN}_{2}$ is risk numbers after control and preventive actions. 
Table 7: $\mathrm{RPN}_{1}, \mathrm{RPN}_{2}$, and Percent of decrease of risks

\begin{tabular}{|c|c|c|c|}
\hline Decrease (\%) & RPN $_{\mathbf{2}}$ & RPN $_{\mathbf{1}}$ & Row \\
\hline 66.67 & 21 & 63 & 1 \\
\hline 66.67 & 12 & 36 & 2 \\
\hline 66.67 & 27 & 81 & 3 \\
\hline 75.00 & 18 & 72 & 4 \\
\hline 66.67 & 12 & 36 & 5 \\
\hline 66.67 & 28 & 84 & 6 \\
\hline 66.67 & 24 & 72 & 7 \\
\hline 66.67 & 21 & 63 & 8 \\
\hline 66.67 & 18 & 54 & 9 \\
\hline 66.67 & 15 & 45 & 10 \\
\hline 66.67 & 18 & 54 & 11 \\
\hline 66.67 & 21 & 63 & 12 \\
\hline 66.67 & 18 & 54 & 13 \\
\hline 66.67 & 21 & 63 & 14 \\
\hline 66.67 & 18 & 54 & 15 \\
\hline
\end{tabular}

Referring to the risk assessment table (table 5) with PHA method, it was identified 15 important hazards. We conclude that $40 \%$ of the risks are undesirable and $60 \%$ are acceptable but need revision which can be mitigated by the preventive and control actions mentioned in table 5. Risk surfaces decreased due to decreasing probability.

With risk assessment using FEMA method, min of risk number is 36 and max of risk number is 84 (table 6 , table 7). Other risk numbers are between these two numbers.

Referring to the RPN numbers obtained in the FMEA method, we conclude that we choose RPN $=72$ which corresponds to row 7 as the final RPN. The reason for this choice is why the formation of free compounds such as iron, copper, lead, nickel and vanadium due to wear of pipelines, storage tanks, valves and piping systems, resulting in the closure and blockage of pipelines and contamination of products which is a critical and undesirable state.

Figure 1 shows a comparison between risk numbers before and after applying preventive and control actions. Table 7 shows the decrease percent of different hazards after applying control actions.

Figure 1, Table 7 shows that all RPN numbers decreased with applying control and preventive actions. This decrease was significantly. This shows that all preventive and control actions are appropriate and effectiveness. Control and preventive actions shows that treating and pre-treating streams included different organic and mineral components is very necessary for preventive of hazards. Also equipment design with appropriate materials that have non-corrosive properties is completely necessary.

\section{Conclusions}

This study showed that a good engineered process design is very necessary and important for preventing of hazards. Also it was showed that concepts of chemistry and chemical engineering can help to a successful risk assessment. Also FMEA is better that PHA method for risk assessment in design and preventive phase. Because FMEA is completely a quantitative method but PHA is a semi-quantitative method.

\section{References:}

[1] Kerzner H . Project management a systems approach to planning, scheduling and controlling, John Wiley \& Sons, New York, 2003.

[2] Wright A. Risk and Un certainty in Construction 2003. http://www.construction.ualberta.ca[Accessed March 2005].

[3] Muhlbauer W . Pipeline Management Manual, 2nd Editio. Gulf Professional Publishing, 1996, P. 438.

[4] Mathews M, Karydas D , Delichatsios M . A performance-based approach for fire safety engineering: A comprehensive engineering risk analysis methodology, a computer model, and a case study, Fifth International Symposium on Fire Safety Science, International Association for Fire Safety Science, 1997, 595-606.

[5] Young-Do J, Daniel A. Individual risk analysis of high-pressure natural gas pipelines, J Loss Preven in the Proc Indus 2008; 21: 58995.

[6] Allen HH, chia-wei H, Tsai-Chi K, Wei-Cheng W. Risk evaluation of green components to hazardous substance using FMEA and FAHP, Ex Sys with Appli 2009; 36: 7142-47.

[7] Waterland LR, S Venkatesh, S Unnasch. Safety and performance assessment of ethanol/diesel blends (E-diesel). 2003: National Renewable Energy Laboratory. 
[8] Xiao N, et al. Multiple failure modes analysis and weighted risk priority number evaluation in FEMA. Engineering Failure Analysis 2011; 18(4): 1162-70.

[9] Zhou J, T Stalhanne. Using FMEA for early robustness analysis of Web-based systems. In Computer software and Application Conference, 2004. COMPSAC 2004. Proceedings of the $28^{\text {th }}$ Annual International. 2004. IEEE.

[10] Faisal I.KhanS.A.Abbasi. TORAP - a new tool for conducting rapid risk-assessments in petroleum refineries and petrochemical industries. Applied Energy. Volume 65, Issues 1-4, April 2000, Pages 187-210

[11] M. JabbariGharabagh ${ }^{\mathrm{a}}$ H.Asilian ${ }^{\mathrm{b}}$ S.B.Mortasavi ${ }^{\mathrm{b}}$ A. Zarringhalam Mogaddam ${ }^{\mathrm{c}}$ E.Hajizadeh $^{\mathrm{d}}$ A.Khavanin $^{\mathrm{b}}$, Comprehensive risk assessment and management of petrochemical feed and product transportation pipelines. Journal of Loss Prevention in the Process Industries. Volume 22, Issue 4, July 2009, Pages 533-539.

[12] Rong-HwaHuang ${ }^{\mathrm{al}} \mathrm{Chang}$-LinYang ${ }^{\mathrm{a}} \mathrm{Chung}-\mathrm{SzuKa}{ }^{\mathrm{b} 1}$, Assessment model for equipment risk management: Petrochemical industry cases. Safety Science. Volume 50, Issue 4, April 2012, Pages 1056-1066.

[13] XU Xiaonan, WANG Fang, HUANG Min, BAI Jing, Li Li, Security quantitative risk analysis of ethylene horizontal tanks of a petrochemical company, Procedia Engineering 45 ( 2012 ) 489 - 495

[14] Wei WuGuang, xu Cheng Hai, jun Hu, Qi Zhou, Risk analysis of corrosion failures of equipment in refining and petrochemical plants based on fuzzy set theory, Engineering Failure Analysis, Volume 32, September 2013, Pages 23-34. 